\title{
KOMUNIKASI ANTAR BUDAYA ETNIS TIONGHOA DAN PENDUDUK MUSLIM DI BANTEN
}

\author{
(Studi Fenomenologi Etnis Tionghoa dan Penduduk Muslim di Pantai Tanjung Kait \\ Tangerang, Banten) \\ Faisal Tomi Saputra \\ Muhiroh \\ Email : ftsaputra@unis.ac.id \\ Program Studi Ilmu Komunikasi, Universitas Islam Syekh-Yusuf Tangerang.
}

\begin{abstract}
ABSTRAK
Indonesia memiliki kebudayaan yang beraneka ragam. Interaksi masyarakat yang saling menghormati dan menghargai perbedaan menjadi kekuatan masyarakat Indonesia. Penelitian ini membahas tentang pola interaksi komunikasi antarbudaya etnis Tionghoa dengan pendudukmuslim yang tinggal di kawasan Pantai Tanjung Kait Tangerang, dan mengetahui apa saja hal-hal yang terkonstruksi dalam komunikasi antarbudaya tersebut dalam konstruksi realitas sosial yang terjadi secara terus-menerus, dan bagaimana persepsi masing-masing kelompok umat beragama serta penilaian yang berbeda terhadap suku lain. Metode penelitian yang digunakan metode kualitatif. Informan dalam penelitian terdiri diwakili oleh masing-masing 3 informan dari masyarakat yang beretnis Tionghoa dan penduduk muslim. Teknik pengumpulan data dilakukan melalui observasi, wawancara, dan dokumentasi. Hasil penelitian ini menunjukkan bahwa komunikasi antarbudaya etnis Tionghoa dengan penduduk muslim di kawasan Pantai Tanjung Kait Tangerang cukup kompleks. Terlihat dari kehidupan bermasyarakat umat beragama yang hidup berdampingan sejak dahulu, sehingga muncul sikap toleransi, partisipasi dan saling menjaga satu sama lain dalam berbagai kegiatan seperti kegiatan agama, budaya, sosial dan ekonomi.
\end{abstract}

\section{Kata Kunci : Komunikasi Antar Budaya, Etnis Tionghoa, Suku Jawa}

\section{ABSTRACT}

Indonesia has cultural diversity. The Interaction of a community who are respecting each other and celebrate diversity strengthen the Indoensian people. This research is to find out how intercultural communication between Chinese ethnic and Muslim residents in the Tanjung Kait Beach area of Tangerang, and to find out what are the things constructed in intercultural communication in the construction of social reality that is happening continuously, and to find out how each perception is different religious groups and judgments about other tribes according to how they feel. The research method used is qualitative. The informants in this study amounted to 6 people, consisting of 3 Chinese communities and 3 Muslim communities. Data collection techniques are done through observation, interviews, and documentation. The results of this study indicate that the communication between Chinese ethnic and Muslim populations in the Tanjung Kait Beach area of Tangerang is quite complex. Seen from the social life of religious communities who have lived side by side in the region so that there is tolerance, participation and mutual care for one another in various activities such as religious, cultural, social and economic activities. Not infrequently in a communication made by the two religious communities of different cultures also experience obstacles in communication.

Keywords: Intercultural Communication, Chinese Ethnic, Muslim Population 


\section{PENDAHULUAN}

Indonesia merupakan salah satu negara yang unik dan memiliki keanekaragamaan budaya berbeda yang terdiri dari ribuan suku, ras, bahasa, agama dan adat istiadat yang beragam. Selain itu banyak bangsa pendatang yang hadir menambah keberagaman suku bangsa di Indonesia. Kepulauan Indonesia sempat menjadi salah satu tempat singgah bangsa-bangsa seperti Cina, India dan Arab untuk berdagang. Hal ini menjadi awal mula mereka menetap dan tinggal di Indonesia hingga menjadi warga Negara Indonesia.

Dalam beragam kebudayaan tersebut, terjadilah interaksi sosial dan kontak budaya antar suku bangsa yang tidak terelakkan. Di satu pihak masing-masing kebudayaan memperlihatkan adanya prinsip-prinsip kesamaan dan saling menyesuaikan antara satu dengan yang lainnya, untuk mewujudkan interaksi yang efektif dengan latar belakang budaya yang berbeda.

Sebuah toleransi menjadi sangat penting dalam berinteraksi dengan berbeda budaya. Toleransi adalah elemen dasar yang dibutuhkan untuk menumbuh kembangkan sikap saling memahami dan menghargai perbedaan yang ada, serta menjadi entry point bagi terwujudnya suasana dialog dan kerukunan antar umat beragama dalam masyarakat (Kementerian Agama RI, 2010, hlm. 2). Seperti saling bertoleransi ketika antar umat beragama sedang menjalankan ibadah atau ritual agama masing-masing. Inilah yang disebut toleransi antar umat beragama saling menghargai dan menghormati kepercayaan satu sama lain.

Kabupaten Tangerang merupakan salah satu wilayah di Propinsi Banten, Indonesia yang memiliki keragaman budaya. Berdasarkan letak geografisnya, Kabupaten Tangerang di bagian utara berbatasan langsung dengan Laut Jawa yang memiliki garis pantai yang panjang. Berbagai pesona bahari tersimpan di garis pantai sepanjang 50 kilometer. Sekitar 500 meter dari Pantai Tanjung Kait terdapat situs sejarah religius yang masih terpelihara. Tempat religius yang juga dikenal dengan nama kelenteng Tanjung Kait atau kelenteng Tso Su Kong yang merupakan tempat ibadah etnis Tionghoa yang berusia 400 tahun (tangerangkab.go.id). Bangunan unik yang memadukan arsitektur Cina dan Banten. Kelenteng yang terletak tidak jauh dari Pantai Tanjung Kait itu semakin dikenal luas karena merupakan satu-satunya bangunan yang bertahan dari guncangan tsunami saat Gunung Krakatau meletus pada tahun 1883. Sejak dibangun pada tahun 1792, hingga saat ini kontruksi klenteng tidak berubah. Dua pagoda setinggi enam meter didepan klenteng menjadi ciri khas tersendiri.

Tidak jauh dari kelenteng Tso Su Kong terdapat masjid Al-Ikrom. Masjid adalah rumah atau bangunan tempat beribadah orang Islam. Terdapat banyak ragam budaya di desa Tanjung Kait, ada penduduk lokal yang mayoritas muslim dan ada etnis Tionghoa sebagai suatu kelompok minoritas yang dianggap sebagai perantauan. Di daerah Tanjung Kait etnis Tionghoa mempunyai lokasi tempat tinggal khusus dan terpisah dengan penduduk lokal, dengan ciri mempunyai budaya khas Tionghoa dan hanya terdapat masyarakat yang beragama Konghucu dan Budha.

Adanya toleransi di antara umat beragama tersebut dalam kegiatan keagamaan yang terjadi antara etnis Tionghoa dan penduduk lokal. Seperti saat umat muslim sebagai penduduk lokal datang ke kelenteng di tempat beribadah etnis Tionghoa untuk berziarah. Di dalam kelenteng tersebut terdapat makam-makam kramat tokoh Islam yang berada di lingkungan etnis Tionghoa. Begitupun ketika seorang etnis Tionghoa yang masuk Islam (mualaf) datang beribadah ke masjid.

Dalam pergaulan sehari-hari kehidupan bermasyarakat antar etnis Tionghoa dan penduduk muslim bergaul seperti masyarakat lainnya, komunikasi terjadi 
tidak hanya untuk pergaulan, perdagangan tetapi sampai pada adanya perpindahan keyakinan dari etnis Tionghoa menjadi seorang muslim. Seperti ingin menjadi muslim karena ingin menikah dengan penduduk lokal yang juga seorang muslim ataupun karena kesehariannya berada di lingkungan penduduk muslim dan menimbulkan ketertarikan pada agama Islam sampai keinginannya menjadi seorang mualaf.

"Interaksi yang terjalin antara etnis Tionghoa dengan penduduk muslim itu sudah berlangsung sejak lama, terbukti dengan adanya makam kuno tokoh Islam yang terdapat di kelenteng Tso Su Kong. Konon sejarahnya pemilik makam itu bernama Embah Rachman disebut Hok Tek Tjeng Sin dianggap sebagai Dewa Bumi. Embah Rachman adalah seorang mualaf juara terkenal bagi daerah Tanjung Kait. Dan terdapat juga makam Dewi Neng seorang mualaf pribumi setempat yang juga anak Kongco Tjo Soe Kong. Makam keramat Dewi Neng dipuja dan dikunjungi oleh para umat muslim. Jadi memang dari dulu sampai sekarang terus berlangsung hubungan interaksi antara etnis Tionghoa dengan penduduk muslim (hasil observasi)".

Etnis Tionghoa memang sudah secara turun-temurun tinggal di kawasan Tangerang. Tetapi masih banyak istilahistilah yang sering menyudutkan masyarakat etnis Tionghoa seperti sombong, pelit, dan lain sebagainya. Etnis Tionghoa memiliki beberapa kecenderungan, seperti pendapat bahwa etnis Tionghoa lebih mementingkan motif prestasi, lebih mementingkan memenuhi kebutuhan pribadi dibandingkan dengan motif membangun persahabatan dengan kelompok lain di luar etnisnya sendiri.

Perhatian terhadap kelompokkelompok minoritas ini menyadarkan kita bahwa komunikasi dengan berbeda budaya itu cukup sulit. Bahkan bila hambatan bahasa bisa diatasi terkadang masih bisa juga gagal memahami dan dipahami. Dampak negatif yang ditimbulkan yakni semakin memperlebar gap communication antara etnis Tionghoa dengan penduduk muslim. Kalangan etnis Tionghoa menjadi lebih tertutup karena merasa dianggap sebelah mata dan tidak diterimanya sebagai warga masyarakat setempat.

Dalam interaksi kedua umat beragama tersebut pasti akan ada persepsi-persepsi yang muncul dalam berkomunikasi satu sama lain, yang akan menjadikan pandangan tersendiri mengenai kepercayaan dan tradisi yang dianut masing-masing kelompok. Dalam proses memberi makna perbedaan budaya yang secara langsung mempengaruhi persepsi kita ketika berkomunikasi dengan orang lain sehingga mendapatkan pengetahuan baru (Mulyana, 2013, hlm. 214). Dengan kata lain, hubungan antara persepsi dengan latar belakang budaya mengubah menjadi informasi.

Penyesuaian-penyesuaian ini akan melahirkan pemahaman kedua umat beragama terhadap makna apapun yang dijumpainya selama proses berinteraksi antar etnis Tionghoa dengan penduduk muslim. Dalam konstruksi realitas sosial yang menggambarkan proses sosial melalui tindakan interaksinya, yang mana individu menciptakan secara terusmenerus suatu realitas yang dimiliki dan dialami bersama secara subjektif (Bungin, 2006). Makna yang berkaitan dengan komunikasi pada hakikatnya merupakan fenomena sosial. Saat berinteraksi dengan orang lain yang berbeda budaya, bukan hanya menginterpretasikan pengalaman pribadi, tetapi juga menginterpretasikan pengalaman orang lain yang dilihat atau diceritakan kepadanya.

Melalui fenomenologi pengalaman tersebut terjadi dikehidupan sehari-hari. Proses interaksi yang dilakukan oleh etnis Tionghoa dengan penduduk muslim dalam konsep fenomenologi akan melahirkan motif tertentu yang dimiliki seseorang, motif tersebut akan berbeda dalam membangun makna di dalam kegiatan keagamaan. Fenomenologi menjadikan pengalaman sebenarnya sebagai data 
utama dalam memahami realitas. Apa yang dapat diketahui seseorang adalah apa yang dialaminya (Morissan, 2018). Dalam konteks ini peneliti akan melihat dan memahami interaksi yag terjadi pada etnis Tionghoa dan penduduk muslim berdasarkan pengalaman hidupnya dan menginterpretasikan pengalaman tersebut dengan memberikan makna atas sesuatu yang dialaminya.

Hubungan yang terjadi antara masyarakat Tionghoa dan masyarakat muslim ialah hubungan komunikasi antarbudaya yang memiliki kebudayaan berbeda. Komunikasi antarbudaya adalah sebuah hubungan komunikasi yang dilatar belakangi oleh perbedaan budaya, di mana orang yang terlibat dalam komunikasi memiliki budaya yang berbeda (Alo Liliweri, 2013).

"Komunikasi antarbudaya menempatkan fokus komunikasi pada identitas budaya yang dimiliki oleh para pelaku budaya di dalamnya. Dengan kata lain komunikasi antarbudaya lebih menitik beratkan pada cara pandang mengenai fakta bahwa budaya sangatlah beragam dan karenanya peristiwa komunikasi antarbudaya bisa muncul ketika melibatkan para pelaku komunikasi yang secara signifikan memiliki perbedaan kelompok budaya pada suatu budaya tertentu". (Sukmono dan Junaedi, 2014).

Umumnya komunikasi antarbudaya terjadi bila produsen pesan adalah anggota suatu budaya dan penerima pesannya adalah anggota suatu budaya lain. Karenanya budaya mempunyai timbal balik dengan komunikasi, dimana budaya menjadi bagian dari perilaku komunikasi dan pada gilirannya komunikasipun turut menentukan, memelihara, mengembangkan, dan mewariskannya.

Keanekaragaman budaya bukanlah sesuatu yang akan hilang pada waktu mendatang, yang memungkinkan kita untuk merencanakan strategi berdasarkan asumsi saling memahami. Asumsi itu sendiri merupakan suatu fenomena dengan kekayaannya sendiri, di mana explorasi yang dapat menghasilkan keuntungan yang tidak ternilai bagi kita, baik dari segi tujuan ataupun kebijakan dan kegiatan yang lebih menguntungkan.

"Orang-orang dari budaya yang berbeda berbagai konsep dasar, tetapi memandang konsep tersebut dari sudut dan persepktif yang berbeda, yang menyebabkan mereka berperilaku dalam suatu cara yang mungkin kita anggap irasional atau bahkan bertentangan langsung dengan apa yang kita anggap sebagai hal yang kramat. Walaupun demikian, kita harus optimis mengenai perbedaan budaya". (Lewis, 2004).

Perbedaan-perbedaan budaya memang dapat menimbulkan resiko yang fatal. Perbedaan budaya dalam komunikasi dapat menyebabkan komunikasi tidak efektif. Pada umumnya orang-orang yang terlibat dalam komunikasi antarbudaya tidak bisa lepas dari latar belakang budaya yang dimiliki sebelumnya. Hal itulah yang bisa menjadi hambatan dalam komunikasi berbeda budaya. Ada tiga problem utama dalam pertukaran komunikasi antarbudaya yang berbeda satu sama lain yaitu bahasa, nilai dan pola budaya.

Dengan demikian komunikasi dalam sebuah hubungan yang multi etnis perlu dilakukan, sebagai salah satu cara dalam menciptakan hubungan yang harmonis. Dalam masyarakat akan terwujud sebuah kesadaran sebagai satu komunitas yang berada dalam satu wilayah Negara Indonesia, serta dapat saling mentoleransi perbedaan-perbedaan tersebut. Salah satu hal yang harus dipertimbangkan ialah keberhasilan setiap etnik dan antar pemeluk agama untuk hidup berdampingan dalam perbedaan-perbedaan budaya, tanpa menamfikan potensi konflik yang ada.

Koentjaraningrat menerangkan bahwa terdapat 7 unsur-unsur kebudayaan universal untuk lebih memudahkan kita memahami kebudayaan yaitu; (1) sistem upacara keagamaan; (2) sistem dan organisasi kemasyarakatan; (3) bahasa; (4) sistem pengetahuan; (5) kesenian; (6) sistem mata pencaharian hidup; (7) sistem 
teknologi dan peralatan (Koetjaraningrat, 1990). Komunikasi antarbudaya adalah komunikasi antar orang-orang yang berbeda kebudayaan, seperti antar suku bangsa, antar etnik dan ras, antar kelas sosial. Komunikasi antarbudaya terjadi di antara produser pesan dan penerima pesan yang latar belakang kebudayaannya berbeda (Liliweri, 2013).

Konstruksi realitas sosial Berger dan Luckmann menjelaskan ada tugas pokok dalam memahami dialektika diri (self) dengan dunia sosiokultural. Dialektika ini berlangsung dalam proses dengan tiga momen simultan. Melalui proses dialektika ini, realitas sosial dapat dilihat dari ketiga tahap (Bungin, 2006). Eksternalisasi (penyesuaian diri) dengan dunia sosiokultural sebagai produk manusia, objektivasi merupakan interaksi sosial yang terjadi dalam dunia intersubjektif yang dilembagakan atau mengalami proses institusionalisasi dan internalisasi yang merupakan proses di mana individu mengidentifikasikan dirinya dengan lembaga-lembaga sosial atau organisasi sosial tempat individu menjadi (Bungin, 2006).

Dalam konsep konstruksi realitas social, kenyataan sosial yang objektif terjadi melalui tiga momen dialektis yang simultan: (1) Eksternalisasi, dalam kegiatan keagamaan etnis Tionghoa dan penduduk muslim, proses ini merupakan bentuk ekspresi diri untuk menguatkan eksistensi individu dalam masyarakat berbeda budaya, (2) Objektivasi, merupakan hasil yang telah dicapai dalam komunikasi yang terjadi dalam kegiatan keagamaaan etnis Tionghoa dan penduduk muslim berupa realitas objektif atau proses interaksi sosial dalam dunia intersubjektif yang di lembagakan atau mengalami proses institusionalisasi, (3) Internalisasi, melalui internalisasi manusia menjadi hasil dari masyarakat, sehingga dapat dikatakan, setiap individu etnis Tionghoa dan penduduk muslim memiliki pengetahuan dan identitas sosial sesuai dengan peran institusional yang terbentuk dalam komunikasi yang terjadi pada keduanya atau yang diperankannya yang akan menghasilkan makna dan persepsi di keduanya.

Komunikasi dalam masyarakat berbeda budaya merupakan suatu proses yang kompleks untuk mencapai kesepakatan demi mencari solusi atas perbedaan latar belakang budaya masyarakat. Peran komunikasi dalam masyarakat berbeda budaya sangat penting, terutama dalam usaha untuk mengurangi ketidakpastian maupun kesalahpahaman yang sering terjadi.

Dalam hal usaha menghindari konflik yang muncul, kedua budaya harus melakukan penyesuaian adaptasi satu sama lain. Penyesuaian tersebut dapat menghasilkan beragam solusi, apakah menganut salah satu budaya, atau menerapkan masingmasing nilai budaya, atau bahkan membentuk budaya baru yang sesuai dengan konteks kejadian dan dengan tetap saling menghormati, menghargai satu sama lain. Pilihan solusi tersebut akan dapat teramati dalam perilaku sehari-hari dalam masyarakat yang berbeda budaya.

\section{METODE PENELITIAN}

Penelitian ini menggunakan metode kualitatif, dengan paradigma konstruktivisme yang meneguhkan asumsi bahwa individu-individu selalu berusaha memahami dunia di mana mereka hidup dan bekerja. Mereka mengembangkan makna-makna subjektif atas pengalamanpengalaman mereka makna-makna yang diarahkan pada objek-objek atau bendabenda tertentu (Creswell, 2013). Paradigma konstruktivisme digunakan untuk melihat fenomena masyarakat umat beragama yaitu etnis Tionghoa dengan penduduk muslim di Pantai Tanjung Kait Tangerang. Dalam penelitian fenomenologi lebih difokuskan perhatiannya terhadap pengalaman sadar seorang individu. Tradisi fenomenologi ini berpandangan bahwa cerita atau pengalaman individu adalah lebih penting 
dan memiliki otoritas lebih besar dari pada hipotesa penelitian sekalipun (Morissan, 2018). Metode pengumpulan data dalam penelitian ini adalah melalui observasi, wawancara dan dokumentasi. Informan dalam penelitian ini berjumlah 6 orang yang terdiri dari 2 informan kunci dan 4 informan inti, terdiri dari 3 masyarakat Tionghoa dan 3 masyarakat muslim.

\section{HASIL DAN PEMBAHASAN}

Konstruksi realitas sosial menurut Peter L. Berger dan Thomas Luckmann, menggambarkan proses sosial melalui tindakan dan interaksinya, yang mana individu menciptakan secara terusmenerus suatu realitas yang dimiliki dan dialami bersama secara subjektif (Bungin, 2006). Komunikasi yang terjadi secara terus-menerus antara masyarakat Tionghoa dan masyarakat muslim yang akhirnya membentuk konstruksi realitas sosial terhadap masyarakat di Pantai Tanjung Kait.

Dalam hal ini interaksi masyarakat Tionghoa dan masyarakat muslim yang berbeda kultur merupakan sebuah hasil fenomena dari konstruksi realitas sosial yang terjadi setiap harinya melalui aspek agama, budaya dan ekonomi. Sehingga melalui komunikasi maka dunia sosial terbentuk dan terjadi pemahaman.

Adanya makna dan kepentingan di dalamnya yang terbangun melalui konstruksi sosial antara masyarakat Tionghoa dan masyarakat muslim, individu-individu didalamnya saling berinteraksi, saling mengkonstruksi dan merekonstruksi yang membentuk realitas sosial.

Konstruksi realitas sosial cenderung pada interaksi untuk mempertanyakan mengenai aktivitas dirinya dan juga mempelajari aktivitas individu lainnya sampai pada saling memiliki pemahaman yang sama, dalam hal ini tercipta melalui dialektika simultan ekternalisasi, objektivasi, dan internalisasi. Dialektika terjadi secara simultan atau dalam rentang waktu bersamaan dengan membentuk pengetahuan masyarakat Tionghoa dan masyarakat muslim, dimana individu menciptakan masyarakat dan masyarakat menciptakan individu.

Kenyataan sosial yang objektif melalui 3 momen dialektis simultan dalam penelitian ini, pertama Eksternalisasi dalam kegiatan keagamaan etnis Tionghoa dan penduduk muslim merupakan proses penyesuain diri terhadap perbedaan kultur yang ada, komunikasi yang terjadi menjadi penyesuaian bagaimana menghadapi masing-masing individu terhadap kultur yang berbeda, seperti penyesuaian diri ketika adanya tradisi keagamaan masingmasing kelompok masyarakat dari pihak masyarakat Tionghoa yaitu seperti Sejit kelenteng Tso Su Kong, Imlek, Cap Go Meh, upacara pernikahan yang rutin dirayakan setiap tahunnya dan dari pihak masyarakat muslim yaitu seperti hari raya Idul Fitri, hari raya Idul Adha, Maulid Nabi Muhammad SAW, Isra Miraj dan kegiatan agama lainnya. Dan karena terdapat makam-makam keramat di dalam kelenteng Tso Su Kong yang merupakan makam tokoh muslim Embah Rachman dan Dewi Neng membuat masyarakat muslim menyesuakian diri dalam ritual berziarah di kelenteng tersebut. Dalam bentuk keagamaan tersebut masing-masing kelompok saling menyesuaikan satu sama lain mengenai perbedaan tradisi ataupun ritual yang dilakukan masing-masing agama dan untuk tetap menjaga nilai-nilai masyarakat yang ada di Pantai Tanjung Kait.

Kedua Objektivasi merupakan hasil yang telah dicapai dalam komunikasi yang terjadi dalam kegiatan keagamaan etnis Tionghoa dan penduduk muslim berupa realitas objektif, dimana masyarakat Tionghoa dan masyarakat muslim memanifestasikan diri dalam kegiatankegiatan yang ada di Pantai Tanjung Kait. Dari kegiatan yang ada dalam tahap eksternalisasi masyarakat Tionghoa dan masyarakat muslim ikut serta kedalam 
bentuk kegiatan keagamaan antar kelompok melalui interaksi yang berlangsung sehari-hari seperti Sejit, Imlek, Cap Go Meh, pernikahan, Idul Fitri, Idul Adha, Maulid, Isra Miraj dan bukan hanya itu berbagai bentuk acara baksos, acara Nasional 17 Agustus. Dalam hal ikut merayakan kegiatan keagamaan yang berlangsung di Pantai Tanjung Kait dan tidak membeda-bedakan kultur masingmasing kelompok, bahkan terkadang masyarakat Tionghoa ataupun masyarakat muslim mengikuti ritual keagamaan walupun berbeda kultur, dan juga mengikuti bahasa-bahasa masing-masing kelompok ketika berinteraksi.

Ketiga Internalisasi melalui internalisasi manusia menjadi hasil dari masyarakat, dimana masyarakat Tionghoa dan masyarakat muslim mengidentifikasikan dirinya dengan organisasi sosial yang ada di Pantai Tanjung Kait. Sehingga dapat memahami diri sendiri dan orang lain serta pemahaman mengenai lingkungan Pantai Tanjung Kait sebagai sesuatu yang maknawi dari kenyataan sosial. Dalam tahap ini masyarakat muslim dan masyarakat Tionghoa saling mengidentifikasikan dirinya masingmasing kedalam bentuk keagamaan yang terjadi, saling memahami satu sama lain karena mereka sadar hidup dengan berbeda kultur yang mengharuskan bertoleransi dan berpartisipasi dalam kegiatan keagamaan yang berlangsung. Seperti dari pihak Tionghoa ikut berpartisipasi ketika masyarakat muslim membutuhkan dana dalam kegiatan keagamaannya dibantu oleh masyarakat Tionghoa secara materi, begitupun ketika masyarakat Tionghoa membutuhkan bantuan dalam hal pengamanan lingkungan saat mereka ingin melaksanakan ibadah dari pihak masyarakat muslim ikut mengamankan agar tidak terjadi hal-hal yang tidak diinginkan, dan mereka saling menjaga, bertoleransi, berpartisipasi satu sama lain.

Konstruksi realitas sosial yang terjadi dalam hal kebiasaan hidup masyarakat
Tionghoa dan masyarakat muslim, seperti peniruan bahasa yang digunakan orang Tionghoa yang menjadikan orang muslim mengikuti bahasanya karena terkonstruksi melalui komunikasi yang terjadi seharihari. Dan dalam hal tradisi budaya karena masyarakat Tanjung Kait hidup dengan dua kultur yang berbeda secara tidak langsung terkonstruksi melalui perayaanperayaan tradisi yang ada, yang awalnya mengenal lalu menjadi penyesuaian atau adaptasi dan terlibat dalam kegiatannya sehingga secara terus-menerus menjadi kebiasaan.

Dalam hal ini agama menjadi salah satu hal yang saling mempengaruhi, bukan mempengaruhi nilai-nilai agama yang di anut, tetapi dalam hal toleransi antar umat beragama masyarakat Tionghoa dan masyarakat muslim mengenai tradisitradisi yang dijalankan. Di karenakan membaurnya dua kultur antar umat beragama yaitu etnis Tionghoa dengan penduduk muslim dikawasan Pantai Tanjung Kait. Sikap mendukung, menghormati, berpartisipasi dalam perbedaan kultur sangat dijaga dalam setiap perayaan budaya yang dilaksanakan masing-masing kelompok.

Komunikasi yang terjadi antara masyarakat Tionghoa dan masyarakat muslim di kawasan Pantai Tanjung Kait saling mempengaruhi budaya masingmasing yang akhirnya terjadi integrasi pada budayanya. Keberhasilan komunikasi antarbudaya merupakan sikap dari adaptasi dan integrasi yang baik, dimana dapat menerima pembauran dan hidup berdampingan. Namun terkadang terjadi hal-hal yang tidak diinginkan karena pihak luar kurang memperhatikan hal tersebut.

Perbedaan kultur yang terjadi di kedua umat beragama menjadi sesuatu yang begitu menarik. Dapat dilihat dari komunkasi yang terjadi dengan berbagai macam budaya dalam kehidupan seharihari di Pantai Tanjung Kait. Untuk menjadi masyarakat yang bisa hidup dengan harmonis, komunikasi antarbudaya harus dijaga dengan baik melalui 
kelompok sosial yang ada di masyarakat tersebut.

Berdasarkan hasil pengamatan yang telah dilakukan di kawasan Pantai Tanjung Kait, terdapat adanya komunikasi antarbudaya dimana komunikasi yang dilakukan oleh individu atau kelompok dengan berbeda kultur. Perbedaan budaya tersebut akan menimbulkan persepsi-persepsi yang berbeda satu sama lain. Dimana setiap orang Tionghoa memiliki persepsi yang berbeda terhadap orang muslim, begitupun sebaliknya. Setiap orang memiliki penafsirannya sendiri sesuai dengan apa yang mereka lihat dan rasakan.

Persepsi merupakan proses menerima, menyeleksi, mengorganisasikan, mengartikan, menguji, dan memberikan reaksi kepada rangsangan panca indera atau data. Penelitian ini menggambarkan bagaimana penilaian dan reaksi orang Tionghoa terhadap orang muslim yang sangat beragam, begitupun sebaliknya mengenai penilaian dan reaksi orang muslim terhadap orang Tionghoa.

Adanya kemiripan budaya dalam persepsi memungkinkan pemberian makna yang sama terhadap suatu peristiwa. Dan adanya perbedaan budaya antara satu dengan yang lainnya pun akan menimbulkan makna yang berbeda pula sesuai budaya masing-masing individu.

Persepsi yang terjadi antara orang Tionghoa dan orang muslim dalam komunikasi sehari-hari mencakup aspek agama, budaya, dan ekonomi. Terdapat beberapa masyarakat yang cenderung lebih suka berkomunikasi dengan sesama sukunya. Karena memiliki kedekatan seperti sifat, bahasa, dan budaya. Penilaian mereka mengenai komunikasi dengan sesama suku lebih memiliki kesamaan, lain hal ketika berkomunikasi dengan suku lain lebih banyak memiliki perbedaan. Dalam hal ini menimbulkan persepsi terhadap suku lain akan di sama ratakan.

Komunikasi yang terjadi antara masyarakat Tionghoa dan masyarakat muslim di kawasan ini sangat kompleks. Terlihat dari sejarah awal kurang diterimanya etnis Tionghoa saat masuk Tangerang dan berbagai peristiwa yang terjadi sebelumya. Yang berdampak pada adanya komunikasi antarbudaya yang terjadi antara masyarakat Tionghoa dan masyarakat muslim yang masih terasa sampai saat ini.

Pembentukan persepsi yang terjadi pada orang Tionghoa dan orang muslim sejatinya melalui interaksi yang terjadi dikedua umat beragama dalam kegiatan sehari-hari melalui aspek agama, budaya dan ekonomi. Persepsi yang muncul membuat asumsi diantara keduanya, ada pembentukan persepsi dengan pemaknaan yang sama dan ada pembentukan persepsi dengan makna yang berbeda satu sama lain.

Dalam hal ini persepsi umum bahwa orang Tionghoa itu pelit, sombong dan tidak membaur. Begitupun persepsi bahwa orang muslim itu teroris dan fanatik. Akan ada kesamaan dan perbedaan persepsi saat berinteraksi yang membuat terciptanya makna-makna baru.

Tidak semua hal yang dipersepsikan orang lain itu benar, bila kita tidak merasakan secara langsung. Seperti penilain bahwa tidak semua orang Tionghoa itu pelit dan sombong yang terjadi di kawasan Pantai Tanjung Kait bahwa orang Tionghoa baik dan membaur, walupun perbedaan kultur itu menjadi hal yang langka dan sulit bersatu. Tetapi karena penilain itu mereka rasakan dalam kehidupan sehari-hari, dan mereka yang merasakan dampaknya, hingga membuat persepsi baru bahwa orang Tionghoa yang berada di kawasan ini baik dan membaur dengan kelompok-kelompok lain terutama dengan orang muslim.

Salah satu aspek yang mendominasi dalam mempersepsi saat berlangsungnya komunikasi yang terjadi di kedua umat beragama yaitu aspek ekonomi. Kegiatan ekonomi yang terjadi di wilayah ini berada di Pelelangan ikan dan kawasan wisata Pantai Tanjung Kait. Dimana terjadi interaksi antara masyarakat Tionghoa dan masyarakat muslim. Antara pedagang 
Tionghoa dan pedagang muslim di keduanya tidak ada persaingan yang sangat mencolok. Tetapi untuk pembeli merasa ragu dan khawatir mengenai produk makanan atau minuman yang ingin mereka beli di pedagang tersebut, karena mayoritas masyarakat Tanjung Kait merupakan orang muslim ataupun untuk wisatawan yang datang seorang muslim, mereka takut produk makanan atau minuman yang dijajakan tidak halal.

Dalam hal ini persepsi yang muncul tersebut karena anggapan bahwa orang Tionghoa itu sama. Kurangnya komunikasi yang menjadi hambatan bagi pedagang Tionghoa untuk mendapat kepercayaan dari masyarakat muslim yang ada. Sehingga sering terjadi hal demikian. Padahal harapan orang Tionghoa, produk dagangan yang mereka jajakan bisa dapat juga dirasakan oleh masyarakat lain sehingga akan hilangnya anggapan bahwa tidak semua sesuatu yang mereka jual tidak halal.

Komunikasi adalah upaya untuk mencapai kesamaan makna. Sesuatu yang diucapkan seseorang dalam sebuah transaksi sangat dipengaruhi pengalaman masa lalunya. Kata transaksi disini mengacu pada adanya proses pertukaran pesan dalam pengiriman dan penerimaan pesan yang secara terus-menerus. Kesalahpahaman komunikasi akan memunculkan pemahamam yang salah terhadap persepsi-persepsi sosial yang disebabkan oleh perbedaan kultur yang mempengaruhi proses persepsi. Sehingga menimbulkan problematika budaya.

Percakapan masyarakat Tionghoa dan masyarakat muslim terjadi dalam berbagai aspek kehidupan sehari-hari. Komunikasi terjadi secara verbal dan non verbal, dimana komunikasi terjadi secara tatap muka antara individu-individu yang memungkinkan secara langsung menangkap reaksi orang lain. Komunikasi yang dinamis dan aktif masing-masing individu antara orang Tionghoa dan orang muslim saling mempertukarkan pesan dan menangkap reaksinya secara langsung yang memunculkan persepsi-persepsi baru.

\section{KESIMPULAN}

Berdasarkan hasil penelitian mengenai komunikasi antar umat beragama etnis Tionghoa dan penduduk muslim di kawasan Pantai Tanjung Kait Tangerang, maka dapat disimpulkan sebagai berikut:

1. Komunikasi antar umat beragama di kawasan Pantai Tanjung Kait Tangerang cukup kompleks, karena kawasan ini terdiri dari beragam etnis dan budaya yang berbeda. Semua itu melalui proses komunikasi antarbudaya dimana adanya pertukaran pesan antara individu atau sekelompok orang terhadap kelompok lain yang memiliki kebudayaan berbeda. Terlihat dari beberapa penilaian masyarakat muslim terhadap perilaku dan sifat masyarakat Tionghoa dalam kehidupan bermasyarakat dan kegiatan keagamaan yang terjadi di kawasan ini, seperti perayaan-perayaan hari raya atau tradisi-tradisi di kedua umat beragama.

2. Antara masyarakat Tionghoa dan masyarakat muslim saat komunikasi antarbudaya terjadi di keduanya, terkait karena mereka hidup berdampingan cukup lama di kawasan Pantai Tanjung Kait. Adanya konstruksi realitas sosial yang terjadi di keduanya secara terus-menerus hingga menjadi kebiasaan. Melalui tahap ekternalisasi, objektivasi dan internalisasi yang dilalui kedua umat beragama tersebut yang menjadikan mereka sebagai produk dari masyarakat, seperti masyarakat Tionghoa ataupun masyarakat muslim saling mengikuti tradisi, bahasa, perayaan dan berbagai ritual keagamaan yang dilakukan masing-masing kelompok tanpa adanya rasa sungkan dan itu salah satu bentuk toleransi karena ingin menjadi bagian dari kelompok tersebut.

3. Fenomena-fenomena yang terjadi di lingkungan masyarakat menuntut untuk menghasilkan kepekaan sosial dalam mengaplikasikan kehidupan bermasyarakat di kawasan Pantai Tanjung Kait Tangerang, komunikasi yang dilakukan 
oleh kedua masyarakat yang berbeda budaya pasti akan selalu ada hambatan dalam komunikasi. Seperti adanya sikap etnosentrisme, stereotip yang akhirnya menimbulkan prasangka pada salah satu pihak yang mana hal ini mencerminkan adanya ketidakmampuan untuk memahami norma dari budaya yang berbeda. Tentunya, agar bisa hidup dengan harmonis, masyarakat tersebut harus memiliki komunikasi antarbudaya yang baik diantara keduanya dengan saling menghargai satu sama lain. Dengan adanya komunikasi antarbudaya yang efektif, menjadikan kawasan Pantai Tanjung Kait dapat hidup berdampingan dengan rukun dan tingginya rasa toleransi. Walaupun pada dasarnya masih ada saja hambatan yang sering terjadi antara keduanya. Tetapi kawasan ini menjadi salah satu kawasan yang kental dengan budaya sehingga patut kita jaga dan lestarikan keasliannya. Hal ini bisa menjadikan contoh bagi kehidupan masyarakat lainnya.

\section{DAFTAR PUSTAKA}

Bungin Burhan. 2006. Sosiologi Komunikasi; Teori, Paradigma, dan Diskursus Teknologi komunikasi di Masyarakat. Jakarta: Kencana Prenada Media Group.

Creswell W. John. 2013. Research Design: Pendekatan Kualitatif, Kuantitatif, dan Mixed. Yogyakarta: Pustaka Pelajar.

Filosa, Gita, Sukmono., dan Fajar, Junaedi 2014 Komunikasi Multikultural. Yogyakarta: Literal Yogyakarta.

Kementerian Agama RI. 2010. Toleransi Beragama Mahasiswa. Jakarta: Badan Litbang dan Diklat Kementerian Agama.

Koetjaraningrat. 1990. Pengantar Ilmu Antropologi. Jakarta: PT. Rineka Cipta.

Lewis, D. Richard. 2004. Komunikasi Bisnis Lintas Budaya. Bandung: PT. remaja rosdakarya.

Liliweri, Alo. 2013. Dasar-dasar Komunikasi Antarbudaya. Yogyakarta: Pustka Pelajar.
Morissan. 2018. Teori Komunikasi Individu Hingga Massa. Jakarta: Prenadamedia Group.

Mulyana, Deddy. 2013, Ilmu Komunikasi. Bandung: PT. Remaja Rosdakarya.

Sugiyono. 2015 Metode Penelitian Kuantitatif, Kualitatif, dan R\&D. Bandung: Alfabeta.

Tangerangkab.go.id, "Mauk detail kontenskpd",http://www.tangerangkab.go.i d/ mauk/detail-konten-skpd/show-beritaskpd/753/79/, diakses pada 30 Maret 2019, pukul 20:24 WIB. 